STEVEns, J., dissenting

\title{
SUPREME COURT OF THE UNITED STATES
}

\author{
No. $03-1027$ \\ DONALD H. RUMSFELD, SECRETARY OF DEFENSE, \\ PETITIONER $v$. JOSE PADILLA AND DONNA R. \\ NEWMAN, AS NEXT FRIEND OF JOSE \\ PADILLA \\ ON WRIT OF CERTIORARI TO THE UNITED STATES COURT OF \\ APPEALS FOR THE SECOND CIRCUIT
}

[June 28, 2004]

Justice STEVEns, with whom Justice SouteR, Justice GINSBURG, and JUSTICE BREYER join, dissenting.

The petition for a writ of habeas corpus filed in this case raises questions of profound importance to the Nation. The arguments set forth by the Court do not justify avoidance of our duty to answer those questions. It is quite wrong to characterize the proceeding as a "simple challenge to physical custody," ante, at 13, that should be resolved by slavish application of a "bright-line rule," ante, at 21, designed to prevent "rampant forum shopping" by litigious prison inmates, ante, at 19. As the Court's opinion itself demonstrates, that rule is riddled with exceptions fashioned to protect the high office of the Great Writ. This is an exceptional case that we clearly have jurisdiction to decide.

\section{I}

In May 2002, a grand jury convened in the Southern District of New York was conducting an investigation into the September 11, 2001, terrorist attacks. In response to an application by the Department of Justice, the Chief Judge of the District issued a material witness warrant authorizing Padilla's arrest when his plane landed in 
Chicago on May 8. ${ }^{1}$ Pursuant to that warrant, agents of the Department of Justice took Padilla (hereinafter respondent) into custody and transported him to New York City, where he was detained at the Metropolitan Correctional Center. On May 15, the court appointed Donna R. Newman, a member of the New York bar, to represent him. She conferred with respondent in person and filed motions on his behalf, seeking his release on the ground that his incarceration was unauthorized and unconstitutional. The District Court scheduled a hearing on those motions for Tuesday, June 11, 2002.

On Sunday, June 9, 2002, before that hearing could occur, the President issued a written command to the Secretary of Defense concerning respondent. "Based on the information available to [him] from all sources," the President determined that respondent is an "enemy combatant," that he is "closely associated with al Qaeda, an international terrorist organization with which the United States is at war," and that he possesses intelligence that, "if communicated to the U. S., would aid U. S. efforts to prevent attacks by al Qaeda" on U. S. targets. App. A to Pet. for Cert. 57a. The command stated that "it is in the interest of the United States" and "consistent with U. S. law and the laws of war for the Secretary of Defense to detain Mr. Padilla as an enemy combatant." Id., at 58a. The President's order concluded: "Accordingly, you are

\footnotetext{
${ }^{1}$ As its authority for detaining respondent as a material witness, the Government relied on a federal statute that provides: "If it appears from an affidavit filed by a party that the testimony of a person is material in a criminal proceeding, and if it is shown that it may become impracticable to secure the presence of the person by subpoena, a judicial officer may order the arrest of the person and treat the person in accordance with the provisions of section $3142 \ldots$ Release of a material witness may be delayed for a reasonable period of time until the deposition of the witness can be taken pursuant to the Federal Rules of Criminal Procedure.” 18 U. S. C. $§ 3144$.
} 
Stevens, J., dissenting

directed to receive Mr. Padilla from the Department of Justice and to detain him as an enemy combatant." Ibid.

On the same Sunday that the President issued his order, the Government notified the District Court in an ex parte proceeding that it was withdrawing its grand jury subpoena, and it asked the court to enter an order vacating the material witness warrant. Padilla ex rel. Newman v. Bush, 233 F. Supp. 2d 564, 571 (SDNY 2002). In that proceeding, in which respondent was not represented, the Government informed the court that the President had designated respondent an enemy combatant and had directed the Secretary of Defense, petitioner Donald Rumsfeld, to detain respondent. Ibid. The Government also disclosed that the Department of Defense would take custody of respondent and immediately transfer him to South Carolina. The District Court complied with the Government's request and vacated the warrant. ${ }^{2}$

On Monday, June 10, 2002, the Attorney General publicly announced respondent's detention and transfer "to the custody of the Defense Department," which he called "a significant step forward in the War on Terrorism." Amended Pet. for Writ of Habeas Corpus, Exh. A, p. 1, Record, Doc. 4. On June 11, 2002, presumably in response to that announcement, Newman commenced this proceeding by filing a petition for a writ of habeas corpus in the Southern District of New York. 233 F. Supp. 2d, at

\footnotetext{
${ }^{2}$ The order vacating the material witness warrant that the District Court entered in the ex parte proceeding on June 9 terminated the Government's lawful custody of respondent. After that order was entered, Secretary Rumsfeld's agents took custody of respondent. The authority for that action was based entirely on the President's command to the Secretary - a document that, needless to say, would not even arguably qualify as a valid warrant. Thus, whereas respondent's custody during the period between May 8 and June 9, 2002, was pursuant to a judicially authorized seizure, he has been held ever since-for two years-pursuant to a warrantless arrest.
} 
571. At a conference on that date, which had been originally scheduled to address Newman's motion to vacate the material witness warrant, the Government conceded that Defense Department personnel had taken custody of respondent in the Southern District of New York. Id., at $571-572$.

\section{II}

All Members of this Court agree that the immediate custodian rule should control in the ordinary case and that habeas petitioners should not be permitted to engage in forum shopping. But we also all agree with Judge Bork that "special circumstances" can justify exceptions from the general rule. Demjanjuk v. Meese, 784 F.2d 1114, 1116 (CADC 1986). See ante, at 22, n. 18. Cf. ante, at 2 (KENNEDY, J., concurring). More narrowly, we agree that if jurisdiction was proper when the petition was filed, it cannot be defeated by a later transfer of the prisoner to another district. Ex parte Endo, 323 U. S. 283, 306 (1944). See ante, at $12-13$.

It is reasonable to assume that if the Government had given Newman, who was then representing respondent in an adversary proceeding, notice of its intent to ask the District Court to vacate the outstanding material witness warrant and transfer custody to the Department of Defense, Newman would have filed the habeas petition then and there, rather than waiting two days. ${ }^{3}$ Under that

\footnotetext{
${ }^{3}$ The record indicates that the Government had not officially informed Newman of her client's whereabouts at the time she filed the habeas petition on June 11. Pet. for Writ of Habeas Corpus 2, \$4 ("On information and belief, Padilla is being held in segregation at the highsecurity Consolidated Naval Brig in Charleston, South Carolina"); Letter from Donna R. Newman to General Counsel of the Department of Defense, June 17, 2002 ("I understand from the media that my client is being held in Charleston, South Carolina in the military brig" (emphasis added)), Amended Pet. for Writ of Habeas Corpus, Exh. A, p. 4,
} 
STEVEns, J., dissenting

scenario, respondent's immediate custodian would then have been physically present in the Southern District of New York carrying out orders of the Secretary of Defense. Surely at that time Secretary Rumsfeld, rather than the lesser official who placed the handcuffs on petitioner, would have been the proper person to name as a respondent to that petition.

The difference between that scenario and the secret transfer that actually occurred should not affect our decision, for we should not permit the Government to obtain a tactical advantage as a consequence of an ex parte proceeding. The departure from the time-honored practice of giving one's adversary fair notice of an intent to present an important motion to the court justifies treating the habeas application as the functional equivalent of one filed two days earlier. See Baldwin v. Hale, 1 Wall. 223, 233

Record, Doc. 4. Thus, while it is true, as the Court observes, that "Padilla was moved from New York to South Carolina before his lawyer filed a habeas petition on his behalf," ante, at 13, what matters for present purposes are the facts available to Newman at the time of filing. When the Government shrouded those facts in secrecy, Newman had no option but to file immediately in the district where respondent's presence was last officially confirmed.

Moreover, Newman was appointed to represent respondent by the District Court for the Southern District of New York. Once the Government removed her client, it did not permit her to counsel him until February 11, 2004. Consultation thereafter has been allowed as a matter of the Government's grace, not as a matter of right stemming from the Southern District of New York appointment. Cf. ante, at 4-5 (KENNEDY, J., concurring). Further, it is not apparent why the District of South Carolina, rather than the Southern District of New York, should be regarded as the proper forum to determine the validity of the "change in the Government's rationale for detaining" respondent. Ante, at 5. If the Government's theory is not "a permissible one," ibid., then the New York federal court would remain the proper forum in this case. Why should the New York court not have the authority to determine the legitimacy of the Government's removal of respondent beyond that court's borders? 


\section{Stevens, J., dissenting}

(1864) ("Common justice requires that no man shall be condemned in his person or property without notice and an opportunity to make his defence"). "The very nature of the writ demands that it be administered with the initiative and flexibility essential to insure that miscarriages of justice within its reach are surfaced and corrected." Harris v. Nelson, 394 U. S. 286, 291 (1969). But even if we treat respondent's habeas petition as having been filed in the Southern District after the Government removed him to South Carolina, there is ample precedent for affording special treatment to this exceptional case, both by recognizing Secretary Rumsfeld as the proper respondent and by treating the Southern District as the most appropriate venue.

Although the Court purports to be enforcing a "brightline rule" governing district courts' jurisdiction, ante, at 21 , an examination of its opinion reveals that the line is far from bright. Faced with a series of precedents emphasizing the writ's "scope and flexibility," Harris, 394 U. S., at 291, the Court is forced to acknowledge the numerous exceptions we have made to the immediate custodian rule. The rule does not apply, the Court admits, when physical custody is not at issue, ante, at 8 , or when American citizens are confined overseas, ante, at 19, n. 16, or when the petitioner has been transferred after filing, ante, at 12-13, or when the custodian is " "present" in the district through his agents' conduct, ante, at 17 . In recognizing exception upon exception and corollaries to corollaries, the Court itself persuasively demonstrates that the rule is not ironclad. It is, instead, a workable general rule that frequently gives way outside the context of " core challenges"” to Executive confinement. Ante, at 6.

In the Court's view, respondent's detention falls within the category of "core challenges" because it is "not unique in any way that would provide arguable basis for a departure from the immediate custodian rule." Ante, at 13 . It 
STEVEns, J., dissenting

is, however, disingenuous at best to classify respondent's petition with run-of-the-mill collateral attacks on federal criminal convictions. On the contrary, this case is singular not only because it calls into question decisions made by the Secretary himself, but also because those decisions have created a unique and unprecedented threat to the freedom of every American citizen.

"[W]e have consistently rejected interpretations of the habeas corpus statute that would suffocate the writ in stifling formalisms or hobble its effectiveness with the manacles of arcane and scholastic procedural requirements." Hensley v. Municipal Court, San Jose-Milpitas Judicial Dist., Santa Clara Cty., 411 U. S. 345, 350 (1973). With respect to the custody requirement, we have declined to adopt a strict reading of Wales v. Whitney, 114 U. S. 564 (1885), see Hensley, 411 U. S., at 350, n. 8, and instead have favored a more functional approach that focuses on the person with the power to produce the body. See Endo, 323 U. S., at 306-307. ${ }^{4}$ In this case, the President entrusted the

\footnotetext{
${ }^{4}$ For other cases in which the immediate custodian rule has not been strictly applied, see Garlotte v. Fordice, 515 U. S. 39 (1995) (prisoner named Governor of Mississippi, not warden, as respondent); California Dept. of Corrections v. Morales, 514 U. S. 499 (1995) (prisoner named Department of Corrections, not warden, as respondent); Wainwright v. Greenfield, 474 U. S. 284 (1986) (prisoner named Secretary of Florida Department of Corrections, not warden, as respondent); Middendorf v. Henry, 425 U. S. 25 (1976) (persons convicted or ordered to stand trial at summary courts-martial named Secretary of the Navy as respondent); Strait v. Laird, 406 U. S. 341, 345-346 (1972) ("The concepts of 'custody' and 'custodian' are sufficiently broad to allow us to say that the commanding officer in Indiana, operating through officers in California in processing petitioner's claim, is in California for the limited purposes of habeas corpus jurisdiction"); Burns v. Wilson, 346 U. S. 137 (1953) (service members convicted and held in military custody in Guam named Secretary of Defense as respondent); United States ex rel. Toth v. Quarles, 350 U.S. 11 (1955) (next friend of ex-service member in military custody in Korea named Secretary of the Air Force as respondent); Ex parte Endo,
} 


\section{Stevens, J., dissenting}

Secretary of Defense with control over respondent. To that end, the Secretary deployed Defense Department personnel to the Southern District with instructions to transfer respondent to South Carolina. Under the President's order, only the Secretary-not a judge, not a prosecutor, not a warden-has had a say in determining respondent's location. As the District Court observed, Secretary Rumsfeld has publicly shown "both his familiarity with the circumstances of Padilla's detention, and his personal involvement in the handling of Padilla's case." 233 F. Supp. 2d, at 574. Having "emphasized and jealously guarded" the Great Writ's "ability to cut through barriers of form and procedural mazes," Harris, 394 U. S., at 291, surely we should acknowledge that the writ reaches the Secretary as the relevant custodian in this case.

Since the Secretary is a proper custodian, the question whether the petition was appropriately filed in the Southern District is easily answered. "So long as the custodian can be reached by service of process, the court can issue a writ 'within its jurisdiction' requiring that the prisoner be brought before the court for a hearing on his claim . . . even if the prisoner himself is confined outside the court's territorial jurisdiction." Braden v. 30th Judicial Circuit Court of Ky., 410 U. S. 484, 495 (1973). ${ }^{5}$ See also Endo, 323 U. S., at 306 ("[T]he court may act if there is a respondent

323 U. S. 283, 304 (1944) (California District Court retained jurisdiction over Japanese-American's habeas challenge to her internment, despite her transfer to Utah, noting absence of any "suggestion that there is no one within the jurisdiction of the District Court who is responsible for the detention of appellant and who would be an appropriate respondent").

${ }^{5}$ Although, as the Court points out, ante, at 16 , the custodian in Braden was served within the territorial jurisdiction of the District Court, the salient point is that Endo and Braden decoupled the District Court's jurisdiction from the detainee's place of confinement and adopted for unusual cases a functional analysis that does not depend on the physical location of any single party. 
STEVEns, J., dissenting

within reach of its process who has custody of the petitioner"). In this case, Secretary Rumsfeld no doubt has sufficient contacts with the Southern District properly to be served with process there. The Secretary, after all, ordered military personnel to that forum to seize and remove respondent.

It bears emphasis that the question of the proper forum to determine the legality of Padilla's incarceration is not one of federal subject-matter jurisdiction. See ante, at 5, n. 7; ante, at 1 (KENNEDY, J., concurring). Federal courts undoubtedly have the authority to issue writs of habeas corpus to custodians who can be reached by service of process "within their respective jurisdictions." 28 U. S. C. $\S 2241$ (a). Rather, the question is one of venue, i.e., in which federal court the habeas inquiry may proceed. ${ }^{6}$ The Government purports to exercise complete control, free from judicial surveillance, over that placement. Venue principles, however, center on the most convenient and efficient forum for resolution of a case, see Braden, 410 U. S., at 493-494, 499-500 (considering those factors in allowing Alabama prisoner to sue in Kentucky), and on the placement most likely to minimize forum shopping by either party, see Eisel v. Secretary of the Army, 477 F. 2d

\footnotetext{
${ }^{6}$ Although the Court makes no reference to venue principles, it is clear that those principles, not rigid jurisdictional rules, govern the forum determination. In overruling Ahrens v. Clark, 335 U. S. 188 (1948), the Court in Braden v. 30th Judicial Circuit Court of Ky., 410 U. S. 484 (1973), clarified that the place of detention pertains only to the question of venue. See id., at 493-495 (applying "traditional venue considerations" and rejecting a stricter jurisdictional approach); id., at 502 (REHNQUisT, J., dissenting) ("Today the Court overrules Ahrens"); Moore v. Olson, 368 F. 3d 757, 758 (CA7 2004) ("[A]fter Braden ... , which overruled Ahrens, the location of a collateral attack is best understood as a matter of venue"); Armentero v. INS, 340 F. 3d 1058, 1070 (CA9 2003) ("District courts may use traditional venue considerations to control where detainees bring habeas petitions" (citing Braden, 410 U. S., at 493-494)).
} 
1251, 1254 (CADC 1973) (preferring such functional considerations to "blind incantation of words with implied magical properties, such as 'immediate custodian'"). ${ }^{7} \mathrm{Cf}$. Ex parte Bollman, 4 Cranch 75, 136 (1807) ("It would . . . be extremely dangerous to say, that because the prisoners were apprehended, not by a civil magistrate, but by the military power, there could be given by law a right to try the persons so seized in any place which the general might select, and to which he might direct them to be carried").

When this case is analyzed under those traditional venue principles, it is evident that the Southern District of New York, not South Carolina, is the more appropriate place to litigate respondent's petition. The Government sought a material witness warrant for respondent's detention in the Southern District, indicating that it would be convenient for its attorneys to litigate in that forum. As a result of the Government's initial forum selection, the District Judge and counsel in the Southern District were familiar with the legal and factual issues surrounding respondent's detention both before and after he was transferred to the Defense Department's custody. Accordingly, fairness and efficiency counsel in favor of preserving venue in the Southern District. In sum, respondent properly filed his petition against Secretary Rumsfeld in the Southern District of New York.

\section{III}

Whether respondent is entitled to immediate release is a question that reasonable jurists may answer in different ways. ${ }^{8}$ There is, however, only one possible answer to the

\footnotetext{
${ }^{7}$ If, upon consideration of traditional venue principles, the district court in which a habeas petition is filed determines that venue is inconvenient or improper, it of course has the authority to transfer the petition. See 28 U. S. C. $\S \S 1404(\mathrm{a}), 1406(\mathrm{a})$.

${ }^{8}$ Consistent with the judgment of the Court of Appeals, I believe that
} 


\section{STEVEns, J., dissenting}

question whether he is entitled to a hearing on the justification for his detention. ${ }^{9}$

At stake in this case is nothing less than the essence of a free society. Even more important than the method of selecting the people's rulers and their successors is the character of the constraints imposed on the Executive by the rule of law. Unconstrained Executive detention for the purpose of investigating and preventing subversive activity is the hallmark of the Star Chamber. ${ }^{10}$ Access to counsel for the purpose of protecting the citizen from official mistakes and mistreatment is the hallmark of due process.

Executive detention of subversive citizens, like detention of enemy soldiers to keep them off the battlefield, may sometimes be justified to prevent persons from launching or becoming missiles of destruction. It may not, however, be justified by the naked interest in using unlawful procedures to extract information. Incommunicado detention for months on end is such a procedure. Whether the information so procured is more or less reliable than that acquired by more extreme forms of torture is of no conse-

the Non-Detention Act, 18 U.S. C. $\$ 4001(a)$, prohibits-and the Authorization for Use of Military Force Joint Resolution, 115 Stat. 224, adopted on September 18, 2001, does not authorize-the protracted, incommunicado detention of American citizens arrested in the United States.

${ }^{9}$ Respondent's custodian has been remarkably candid about the Government's motive in detaining respondent: "'[O]ur interest really in his case is not law enforcement, it is not punishment because he was a terrorist or working with the terrorists. Our interest at the moment is to try and find out everything he knows so that hopefully we can stop other terrorist acts.'” 233 F. Supp. 2d 564, 573-574 (SDNY 2002) (quoting News Briefing, Dept. of Defense (June 12, 2002), 2002 WL 22026773).

${ }^{10}$ See Watts v. Indiana, 338 U. S. 49, 54 (1949) (opinion of Frankfurter, J.). "There is torture of mind as well as body; the will is as much affected by fear as by force. And there comes a point where this Court should not be ignorant as judges of what we know as men." Id., at 52 . 
STEVENS, J., dissenting

quence. For if this Nation is to remain true to the ideals symbolized by its flag, it must not wield the tools of tyrants even to resist an assault by the forces of tyranny.

I respectfully dissent. 